\title{
Awareness of Elementary School Teachers in Tribal Areas of Odisha, India about RTE Act, 2009
}

\author{
Sudarshan Mishra, PhD. (Education) \\ Head, Department of Education, Ravenshaw University, Cuttack, Odisha, India
}

\begin{abstract}
RTE Act, 2009 of Government of India has been put into implementation with effect from 1st April, 2010. It came into force in Odisha, one of the states of India from 27th September, 2010. The Govt. of Odisha has taken various earnest steps towards implementation of RTE Act 2009. There are 62 tribes in Odisha with $22.21 \%$ of the total population of the State (Sahu, 2014). The rate of literacy among the Scheduled Tribes is 52.24\% against the overall literacy rate of $72.87 \%$ of the State as per 2011 census. In tribal areas, the development with respect to economic, political and educational is lagging as compared to rest of the country. There is dearth of studies particularly, related to awareness of teachers about RTE Act in tribal areas of Odisha. Hence, the investigator was keen to undertake a study about the extent of awareness of elementary school teachers about RTE Act. survey method is used for the present study. Population of the present study is all the elementary schools of tribal areas of Odisha. Target population is restricted to all the elementary schools of four tribal districts of Odisha. Cluster sampling method was used. Six blocks were selected from these four districts- two blocks from Nabarangpur, two blocks from Koraput, one block each from Kalahandi and Mayurbhanj purposively. These blocks come under scheduled area. Ten elementary schools were selected randomly from each district. All the available teachers were selected from these schools. There were a total of 127 teachers. An awareness test for teachers was developed and used by the investigator. It was found that elementary school teachers in tribal areas of Odisha are aware about Right to Education Act. However, no significant difference was found in awareness about RTE Act among teachers on the bases of their gender, educational and professional qualification, teaching experience, mother and age.
\end{abstract}

Keywords: Awareness, Elementary school teachers, tribal areas of Odisha, RTE Act, 2009.

DOI: $10.7176 / \mathrm{JEP} / 10-1-02$

\section{Backdrop}

The Right of children to free and Compulsory Education Act 2009 (RTE Act, 2009) is a detailed and comprehensive piece of legislation of Government of India which includes provision related to schools, teachers, curriculum, evaluation, access and specific division of duties and responsibilities of different stakeholders. The Act has been put into implementation with effect from $1^{\text {st }}$ April, 2010. It says, Every child of the age of six to fourteen years shall have a right to free and compulsory education in a neighbourhood school till completion of elementary education (Section 3.1). Odisha is one of the 29 states of India, located in eastern India. Elementary school includes classes I to VIII. In exercise of the power conferred by section 38 of the RTE Act, 2009, the Government of Odisha formulated and implemented "The Right of Children to Free and Compulsory Education Rule, 2010". It came into force from $27^{\text {th }}$ September, 2010. The spirit of the Government of Odisha rule as regards to free elementary education is same like that of the RTE Act, 2009. It includes issues in relation to implementation of rules in local conditions.

The Govt. of Odisha has taken various earnest steps towards implementation of RTE Act 2009 like: release of the Orissa Right of Children to Free and Compulsory Education Rule, 2010; Consultation with various stakeholders for environment building for right to education; Orientation, sensitization and capacity development of various stakeholders; establishment of a dedicated RTE cell in School and Mass Education Department; Introduction of school monitoring system (Samiksha) to enhance effectiveness of the functioning of the school system; Introduction of Sadhan and Samadhan for building the capacity of the teacher; Establishment of Grievance Redressal cell and students' Helpline, etc. Since, it has been implemented since 2010, it is expected that all the stakeholders must be aware about the fundamental features of RTE Act.

There are 62 tribes in Odisha with $22.21 \%$ of the total population of the State (Sahu, 2014). The rate of literacy among the Scheduled Tribes is $52.24 \%$ against the overall literacy rate of $72.87 \%$ of the State as per 2011 census. The tribal male and female literacy rates are $63.70 \%$ and $41.20 \%$ respectively. Over the last decade, there has been a significant improvement in literacy level among the STs in the State, which recorded an increase from $37.37 \%$ in 2001 to $52.24 \%$ in 2011 (Government of Odisha, 2016). As per OPEPA (2015, p.13), the share of ST students enrolment at elementary level in Odisha is 30.21 during 2014-15. This shows a steady increase in enrolment trend of ST children in Odisha.

While reviewing literature, the investigator came across contradictory findings on awareness of teachers about RTE Act. Soni (2013) found that most of the teachers are aware about provisions of RTE Act. But, Thakur (2014), Choudhary (2014) and Sarvapalli, (2012) found that the overall level of awareness on RTE act was poor 
among teachers. The awareness of RTE Act was high among those teachers who attended more number of training programs on RTE Act (Mahanadi, 2014). Significant difference was found about the awareness of RTE Act on the basis of gender (Islam \& Chakraborty, 2013; Abdul and Rajan, 2008; Kumar, 2014; Krishnarao \& Mangesh, 2015; Kaur, 2015 and Mahanadi, 2014), locality (Thakur, 2014 and Kaur 2015), management (Mahanadi, 2014; Kumari \& Allam, 2014; Abdul and Rajan, 2008), marital status (Kumar, 2014), experience (Kumar, 2014) and stream of study (Kaur, 2015). Whereas, no significant difference was found in awareness of teachers on the basis of gender (Kumar, 2015; Patel, 2015; Kumari \& Allam, 2014; Thakur, 2014), management (Krishnarao \& Mangesh, 2015; Kumar, 2015), locality (Kumar, 2015; Islam \& Chakraborty, 2013; Abdul and Rajan, 2008), stream of study (Kumar, 2015; Islam \& Chakraborty, 2013) and parental educational level (Kumar, 2015). There is no significant difference in the awareness of RTE Act, 2009 among the prospective teachers on the basis of nature of the college (Kumar, 2015).

The investigator came across contradictory findings while reviewing literature on awareness of teachers about RTE Act in relation to their gender, locality, management, marital status, stream of study and parental educational level. In tribal areas, the development with respect to economic, political and educational is lagging as compared to rest of the country. There is dearth of studies particularly, related to awareness of teachers about RTE Act in tribal areas of Odisha. Hence, the investigator was keen to undertake a study about the extent of awareness of elementary school teachers about RTE Act.

\section{Methodology}

Since, the investigator studied the awareness level of teachers in tribal areas of Odisha, survey method is used for the present study. Population of the present study is all the elementary schools of tribal areas of Odisha. Target population is restricted to all the elementary schools of four tribal districts of Odisha: Mayurbhanj, Kalahandi, Koraput and Nabarangpur. The entire district of Mayurbhanj, Koraput and Nabarangpur come under scheduled area. Th. Rampur and Lanjigarh blocks of Kalahandi district come under scheduled area. Cluster sampling method was used. Six blocks were selected from these four districts- two blocks from Nabarangpur, two blocks from Koraput, one block each from Kalahandi and Mayurbhanj purposively. These blocks come under scheduled area. Ten elementary schools were selected randomly from each district. All the available teachers were selected from these schools. There were a total of 127 teachers.

An awareness test for teachers was developed and used by the investigator. It consisted of 34 multiplechoice items. Four alternatives were given against each item out of which one was correct answer. The dimension-wise distribution of items is given in the following table-1.

Table-1: Dimension-wise Distribution of Awareness Test for Teachers

\begin{tabular}{|l|l|l|}
\hline S. No. & \multicolumn{1}{|c|}{ Dimensions } & Number of items (Total=34) \\
\hline 1. & Preliminary & 08 \\
\hline 2. & Right to Free and Compulsory Education & 05 \\
\hline 3. & Provision for weaker sections & 02 \\
\hline 4. & Admission guidelines & 07 \\
\hline 5. & Duties of stakeholders & 03 \\
\hline 6. & School Management & 09 \\
\hline
\end{tabular}

The data collection work started from the month of January, 2016 and continued till December, 2016. The data were analysed by using both descriptive and inferential statistics. Results were presented both graphically and tabular forms.

\section{Results}

Overall Awareness of teachers about RTE Act

Overall awareness of teachers about RTE Act are analyzed using descriptive statistics as given in the following table- 3 and fig- 1 .

Table-3: Overall awareness of teachers about RTE Act

\begin{tabular}{|l|l|l|l|l|l|l|l|l|l|}
\hline & $\mathbf{N}$ & Mean & Median & Mode & S.E of Mean & Std. Deviation & Variance & Skewness & Kurtosis \\
\hline Awareness & 126 & 21.13 & 21.0 & 23.0 & 0.286 & 3.216 & 10.342 & -.026 & -.612 \\
\hline
\end{tabular}




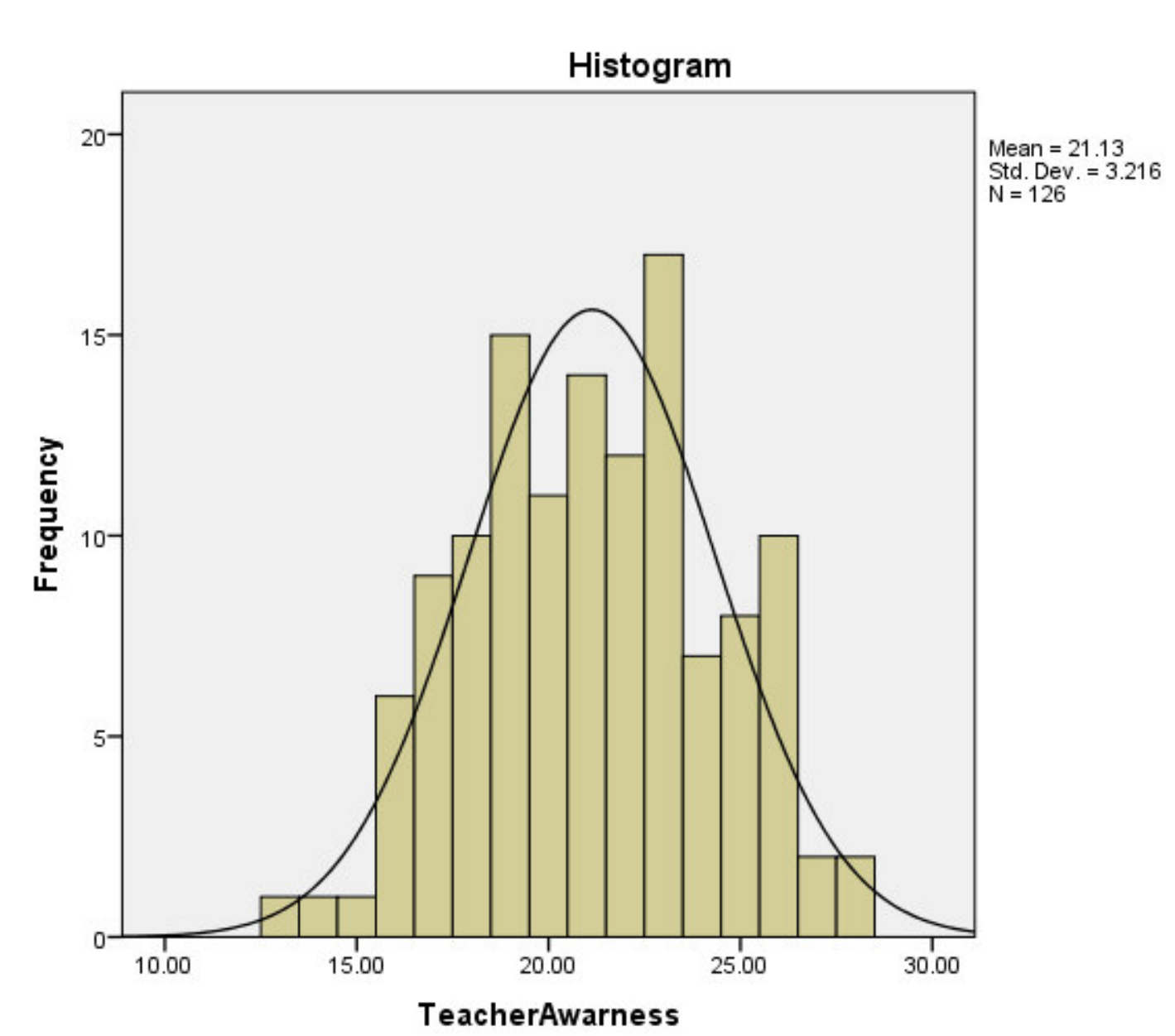

Graph-1: Histogram of overall awareness of teachers about RTE Act

Table-3 depicts the mean, median, mode, standard deviation, skewness and kurtosis of awareness test score of teachers. Graph-1 depicts the distribution of teachers' awareness score. The value of mean, median and mode are 21.13, 21.0 and 23.0. Standard deviation of 3.216 represent the marginal scattered scores from the mean position. The value of skewness is -0.26 that shows the distribution is negatively skewed which shows more individuals score more than the average score in their group. The value of kurtosis is -0.612 that shows the distribution of kurtosis is greater than the normal distribution i.e. 0.263 . Thus, the curve is platykurtic. It can be concluded that the elementary school teachers in tribal areas of Odisha are aware about Right to Education Act. Similar finding was also made by Soni (2013). However, it contradicts to the findings made by Thakur (2014), Choudhary (2014) and Sarvapalli, (2012).

RTE Act 2009 is now included in the curriculum of preservice teacher education programme. Teachers are exposed to different inservice training programme on RTE Act. This may be the reason for their awareness about RTE Act.

Comparison on overall awareness of teachers of Kalahandi, Nabarangapur, Mayurbhanj and Koraput Districts about RTE Act

In order to study the inter-districts comparison on overall awareness of teachers of Kalahandi, Nabarangapur, Mayurbhanj and Koraput Districts about RTE Act, data has been analyzed in the following table-4. 
Table-4: Summary of ANOVA depicting overall and component-wise awareness scores of teachers about RTE Act of Kalahandi, Nabarangapur, Mayurbhanj and Koraput Districts

\begin{tabular}{|c|c|c|c|c|c|c|}
\hline Components & Sources & df & Sum of squares & Mean square & F-ratio & p-value \\
\hline \multirow{3}{*}{ Preliminary } & Between groups & 3 & 2.595 & .865 & \multirow{3}{*}{.710} & \multirow{3}{*}{0.548} \\
\hline & Within groups & 122 & 148.683 & 1.219 & & \\
\hline & Error & 125 & 151.278 & & & \\
\hline \multirow{3}{*}{ RFCE } & Between groups & 3 & 1.585 & .528 & \multirow{3}{*}{2.160} & \multirow{3}{*}{0.096} \\
\hline & Within groups & 122 & 29.843 & .245 & & \\
\hline & Error & 125 & 31.429 & & & \\
\hline \multirow{3}{*}{ Provision for weaker section } & Between groups & 3 & 1.299 & .433 & \multirow{3}{*}{2.339} & \multirow{3}{*}{0.077} \\
\hline & Within groups & 122 & 22.574 & .185 & & \\
\hline & Error & 125 & 23.873 & & & \\
\hline \multirow{3}{*}{ Admission guidelines } & Between groups & 3 & .772 & .257 & \multirow{3}{*}{1.581} & \multirow{3}{*}{0.198} \\
\hline & Within groups & 122 & 19.863 & .163 & & \\
\hline & Error & 125 & 20.635 & & & \\
\hline \multirow{3}{*}{ Duties of stakeholders } & Between groups & 3 & .410 & .137 & \multirow{3}{*}{.629} & \multirow{3}{*}{0.598} \\
\hline & Within groups & 122 & 26.519 & .217 & & \\
\hline & Error & 125 & 26.929 & & & \\
\hline \multirow{3}{*}{ School management } & Between groups & 3 & 7.889 & 2.630 & \multirow{3}{*}{1.573} & \multirow{3}{*}{0.199} \\
\hline & Within groups & 122 & 203.984 & 1.672 & & \\
\hline & Error & 125 & 211.873 & & & \\
\hline \multirow{3}{*}{ Overall } & Between groups & 3 & 125.304 & 41.768 & \multirow{3}{*}{$4.365^{*}$} & \multirow{3}{*}{0.006} \\
\hline & Within groups & 122 & 1167.402 & 9.569 & & \\
\hline & Error & 125 & 1292.706 & & & \\
\hline
\end{tabular}

*Significant at 0.01 level of significance

It is revealed from the above table-4 that the calculated F-ratio of all components of awareness of teachers about RTE Act among four districts are not significant at 0.05 level of significance with df $3 / 122$ except in overall awareness of teachers about RTE Act among four districts whose calculated F ratio (4.365) is significant at 0.01 level of significance as p-value is 0.006 . It indicates that there is a significant difference in the awareness about RTE Act among elementary school teachers in tribal areas of Kalahandi, Nabarangpur, Mayurbhanj and Koraput districts. Similar finding was also made by Thakur (2014) and Kaur (2015).

In order to identify exact difference among districts, Tukey HSD test of multiple comparisons was calculated. This is given in the following table-4.5.

Table-4.5: Multiple Comparisons

\begin{tabular}{|c|c|c|c|c|c|}
\hline Variables & District(I) & District(J) & \begin{tabular}{|l|} 
Mean \\
Difference
\end{tabular} & $\begin{array}{l}\text { Standard } \\
\text { Error }\end{array}$ & $\begin{array}{l}\text { p- } \\
\text { value }\end{array}$ \\
\hline \multirow{3}{*}{$\begin{array}{l}\text { Overall Awareness of Teachers about } \\
\text { RTEAct }\end{array}$} & \multirow[b]{3}{*}{ Kalahandi } & Nabarangpur & 1.49 & .75 & .200 \\
\hline & & Mayurbhanj & 1.49 & .75 & .200 \\
\hline & & Koraput & $2.911^{*}$ & .80556 & .002 \\
\hline
\end{tabular}

The mean difference between Kalahandi and Nabarangpur (1.489) and Kalahandi and Mayurbhanj (1.489) districts on overall awareness of teachers about RTE Act are not significant at 0.05 level of significance as pvalue is 0.200 . In case of the mean difference between Kalahandi and Koraput (2.911) districts on overall awareness of teachers about RTE Act is significant at 0.01 level of significance as p-value is 0.002 . It means that the teachers of Kalahandi District are significantly more aware than the teachers of Koraput district about RTE Act. Similar finding was also made by Thakur (2014) and Kaur (2015).

\section{Awareness of Teachers about RTE Act with reference to Gender}

In order to study the overall and component wise awareness of teachers about RTE Act with reference to gender, the data was analyzed in the following table-5. 
Table-5: Significance of difference in mean scores of overall and component-wise awareness of male and female teachers about RTE Act

\begin{tabular}{|c|c|c|c|c|c|c|c|}
\hline Variables & Gender & $\mathbf{N}$ & Mean & SD & SED & t-ratio & P value \\
\hline \multirow{2}{*}{ Preliminary } & Male & 68 & 4.367 & 1.171 & \multirow{2}{*}{0.196} & \multirow{2}{*}{0.993} & \multirow{2}{*}{.323} \\
\hline & Female & 58 & 4.172 & 1.011 & & & \\
\hline \multirow{2}{*}{ RFCE } & Male & 68 & .470 & .503 & \multirow{2}{*}{0.998} & \multirow{2}{*}{0.135} & \multirow{2}{*}{.893} \\
\hline & Female & 58 & .482 & .504 & & & \\
\hline \multirow{2}{*}{ Provision for weaker section } & Male & 68 & .764 & .427 & \multirow{2}{*}{0.078} & \multirow{2}{*}{0.518} & \multirow{2}{*}{.605} \\
\hline & Female & 58 & .724 & .451 & & & \\
\hline \multirow{2}{*}{ Admission guidelines } & Male & 68 & .735 & .445 & \multirow{2}{*}{0.072} & \multirow{2}{*}{1.760} & \multirow{2}{*}{.081} \\
\hline & Female & 58 & .862 & .348 & & & \\
\hline \multirow{2}{*}{ Duties of stakeholders } & Male & 68 & .676 & .471 & \multirow{2}{*}{0.083} & \multirow{2}{*}{0.365} & \multirow{2}{*}{.715} \\
\hline & Female & 58 & .706 & .459 & & & \\
\hline \multirow{2}{*}{ School management } & Male & 68 & 4.985 & 1.072 & \multirow{2}{*}{0.233} & \multirow{2}{*}{0.158} & \multirow{2}{*}{.874} \\
\hline & Female & 58 & 4.948 & 1.538 & & & \\
\hline \multirow{2}{*}{ Overall } & Male & 68 & 21.558 & 3.063 & \multirow{2}{*}{0.571} & \multirow{2}{*}{1.612} & \multirow{2}{*}{.109} \\
\hline & Female & 58 & 20.637 & 3.344 & & & \\
\hline
\end{tabular}

The obtained t-ratio of overall (1.612) and all components $(0.135,0.135,0.518,1.760,0.365$ and 0.158$)$ of awareness of male and female teachers about RTE Act is not significant at 0.05 levels of significance. It means that there is no significant difference in the mean awareness scores of male and female teachers in all the components of RTE Act. Similar finding was also made by Kumar (2015), Patel (2015), Kumari \& Allam (2014) and Thakur (2014). This contradicts to the finding of Islam \& Chakraborty (2013), Abdul and Rajan (2008), Kumar (2014), Krishnarao \& Mangesh (2015), Kaur (2015) and Mahanadi (2014).

Awareness of Teachers about RTE Act with reference to Educational Qualification

In order to study the overall and component wise awareness of teachers about RTE Act with reference to their educational qualification, the data was analyzed through one-way ANOVA in the following table-6.

Table-6: Summary of ANOVA depicting overall and component wise awareness scores of teachers about RTE Act belonging to Intermediate, graduation and PG and above qualification

\begin{tabular}{|c|c|c|c|c|c|c|}
\hline Components & Sources & df & Sum of squares & Mean square & F-ratio & p-value \\
\hline \multirow{3}{*}{ Preliminary } & Between groups & 2 & 5.927 & 2.963 & \multirow{3}{*}{2.508} & \multirow{3}{*}{.086} \\
\hline & Within groups & 123 & 145.351 & 1.182 & & \\
\hline & Error & 125 & 151.278 & & & \\
\hline \multirow{3}{*}{ RFCE } & Between groups & 2 & .086 & .043 & \multirow{3}{*}{.168} & \multirow{3}{*}{.845} \\
\hline & Within groups & 123 & 31.343 & .255 & & \\
\hline & Error & 125 & 31.429 & & & \\
\hline \multirow{3}{*}{ Provision for weaker section } & Between groups & 2 & .145 & .073 & \multirow{3}{*}{.377} & \multirow{3}{*}{.687} \\
\hline & Within groups & 123 & 23.728 & .193 & & \\
\hline & Error & 125 & 23.873 & & & \\
\hline \multirow{3}{*}{ Admission guidelines } & Between groups & 2 & .051 & .026 & \multirow{3}{*}{.154} & \multirow{3}{*}{.858} \\
\hline & Within groups & 123 & 20.583 & .167 & & \\
\hline & Error & 125 & 20.635 & & & \\
\hline \multirow{3}{*}{ Duties of stakeholders } & Between groups & 2 & .042 & .021 & \multirow{3}{*}{.095} & \multirow{3}{*}{.909} \\
\hline & Within groups & 123 & 26.887 & .219 & & \\
\hline & Error & 125 & 26.929 & & & \\
\hline \multirow{3}{*}{ School management } & Between groups & 2 & 4.978 & 2.489 & \multirow{3}{*}{1.480} & \multirow{3}{*}{.232} \\
\hline & Within groups & 123 & 206.895 & 1.682 & & \\
\hline & Error & 125 & 211.873 & & & \\
\hline \multirow{3}{*}{ Overall } & Between groups & 2 & 18.009 & 9.005 & \multirow{3}{*}{.869} & \multirow{3}{*}{.422} \\
\hline & Within groups & 123 & 1274.697 & 10.363 & & \\
\hline & Error & 125 & 1292.706 & & & \\
\hline
\end{tabular}

From the above table-6, no significant difference was found in overall and component wise awareness of teachers about RTE Act with reference to their educational qualification.

\section{Awareness of Teachers about RTE Act with reference to Professional Qualification}

In order to study the overall and component wise awareness of teachers about RTE Act with reference to their educational qualification, the data was analyzed through one way ANOVA in the following table-7. 
Table-7: Summary of ANOVA depicting overall and component wise awareness scores of teachers about RTE Act belonging to D.Ed., B.Ed. and untrained

\begin{tabular}{|c|c|c|c|c|c|c|}
\hline Components & Sources & dff & Sum of squares & Mean square & F-ratio & p-value \\
\hline \multirow[t]{3}{*}{ Preliminary } & Between groups & 2 & 5.717 & 2.859 & \multirow{3}{*}{2.416} & \multirow{3}{*}{.094} \\
\hline & Within groups & 123 & 145.561 & 1.183 & & \\
\hline & Error & 125 & 151.278 & & & \\
\hline \multirow[t]{3}{*}{ RFCE } & Between groups & 2 & .637 & .319 & \multirow{3}{*}{1.273} & \multirow{3}{*}{.284} \\
\hline & Within groups & 123 & 30.791 & .250 & & \\
\hline & Error & 125 & 31.429 & & & \\
\hline \multirow[t]{3}{*}{ Provision for weaker section } & Between groups & 2 & .411 & .205 & \multirow{3}{*}{1.077} & \multirow{3}{*}{.344} \\
\hline & Within groups & 123 & 23.462 & .191 & & \\
\hline & Error & 125 & 23.873 & & & \\
\hline \multirow[t]{3}{*}{ Admission guidelines } & Between groups & 2 & .410 & .205 & \multirow{3}{*}{1.246} & \multirow{3}{*}{.291} \\
\hline & Within groups & 123 & 20.225 & .164 & & \\
\hline & Error & 125 & 20.635 & & & \\
\hline \multirow[t]{3}{*}{ Duties of stakeholders } & Between groups & 2 & .953 & .477 & \multirow{3}{*}{2.257} & \multirow{3}{*}{.109} \\
\hline & Within groups & 123 & 25.975 & .211 & & \\
\hline & Error & 125 & 26.929 & & & \\
\hline \multirow{3}{*}{ School management } & Between groups & 2 & 7.453 & 3.727 & \multirow{3}{*}{2.242} & \multirow{3}{*}{.111} \\
\hline & Within groups & 123 & 204.420 & 1.662 & & \\
\hline & Error & 125 & 211.873 & & & \\
\hline \multirow[t]{3}{*}{ Overall } & Between groups & 2 & 32.014 & 16.007 & \multirow{3}{*}{1.562} & \multirow{3}{*}{.214} \\
\hline & Within groups & 123 & 1260.693 & 10.250 & & \\
\hline & Error & 125 & 1292.706 & & & \\
\hline
\end{tabular}

From the above table-7, no significant difference was found in overall and component wise awareness of teachers about RTE Act with reference to their professional qualification.

Awareness of teachers about RTE Act with reference to teaching experience

In order to study the overall and component wise awareness of teachers about RTE Act with reference to their teaching experience, the data was analyzed through one way ANOVA in the following table-8.

Table-8: Summary of ANOVA depicting overall and component wise awareness of teachers about RTE Act belonging to less than 5, 5 to 10 years, 11 to 20 years and above 20 years teaching experience

\begin{tabular}{|c|c|c|c|c|c|c|}
\hline Components & Sources & df & Sum of squares & Mean square & F-ratio & p-value \\
\hline \multirow[t]{3}{*}{ Preliminary } & Between groups & 4 & 5.717 & 1.429 & \multirow{3}{*}{1.188} & \multirow{3}{*}{.320} \\
\hline & Within groups & 121 & 145.561 & 1.203 & & \\
\hline & Error & 125 & 151.278 & & & \\
\hline \multirow[t]{3}{*}{ RFCE } & Between groups & 4 & 2.478 & .620 & \multirow{3}{*}{$2.590 *$} & \multirow{3}{*}{.040} \\
\hline & Within groups & 121 & 28.950 & .239 & & \\
\hline & Error & 125 & 31.429 & & & \\
\hline \multirow[t]{3}{*}{ Provision for weaker section } & Between groups & 4 & 1.769 & .442 & \multirow{3}{*}{2.421} & \multirow{3}{*}{.052} \\
\hline & Within groups & 121 & 22.104 & .183 & & \\
\hline & Error & 125 & 23.873 & & & \\
\hline \multirow[t]{3}{*}{ Admission guidelines } & Between groups & 4 & .782 & .195 & \multirow{3}{*}{1.191} & \multirow{3}{*}{.318} \\
\hline & Within groups & 121 & 19.853 & .164 & & \\
\hline & Error & 125 & 20.635 & & & \\
\hline \multirow[t]{3}{*}{ Duties of stakeholders } & Between groups & 4 & 1.672 & .418 & \multirow{3}{*}{2.003} & \multirow{3}{*}{.098} \\
\hline & Within groups & 121 & 25.256 & .209 & & \\
\hline & Error & 125 & 26.929 & & & \\
\hline \multirow{3}{*}{ School management } & Between groups & 4 & 9.440 & 2.360 & \multirow{3}{*}{1.411} & \multirow{3}{*}{.234} \\
\hline & Within groups & 121 & 202.433 & 1.673 & & \\
\hline & Error & 125 & 211.873 & & & \\
\hline \multirow[t]{3}{*}{ Overall } & Between groups & 4 & 45.830 & 11.457 & \multirow{3}{*}{1.112} & \multirow{3}{*}{.354} \\
\hline & Within groups & 121 & 1246.877 & 10.305 & & \\
\hline & Error & 125 & 1292.706 & & & \\
\hline
\end{tabular}

* significant at 0.05 level of significance

It is revealed from the above table- 8 that the calculated F-ratio of all components of awareness of teachers about RTE Act among four categories of teachers on the basis of teaching experiences are not significant at 0.05 
level of significance with df 4/121 except in awareness of teachers about RTE Act in the component Right of children to free education (RCFE) whose calculated F ratio (2.590) is significant at 0.05 level of significance as $\mathrm{p}$-value is 0.04. It indicates that there is a significant difference in the awareness about RTE Act in the component Right of children to free education (RCFE) among four categories of elementary school teachers on the basis of teaching experiences which contradicts to the earlier finding by Kumar (2014).

Awareness of teachers about RTE Act with reference to their mother tongue

In order to study the overall and component wise awareness of teachers about RTE Act with reference to their mother tongue, the data was analyzed in the following table-9.

Table-9: Significance of difference in the mean scores of overall and component wise awareness of teachers about RTE Act with reference to their mother tongue

\begin{tabular}{|c|c|c|c|c|c|c|c|}
\hline Variables & Gender & $\mathbf{N}$ & Mean & SD & SED & t-ratio & P value \\
\hline \multirow[t]{2}{*}{ Preliminary } & Odia & 91 & 4.3626 & 1.11072 & \multirow[t]{2}{*}{.217} & \multirow[t]{2}{*}{1.402} & \multirow[t]{2}{*}{.164} \\
\hline & Local language & 35 & 4.0571 & 1.05560 & & & \\
\hline \multirow[t]{2}{*}{ RFCE } & Odia & 91 & .5055 & .50274 & \multirow[t]{2}{*}{.099} & \multirow[t]{2}{*}{1.058} & \multirow[t]{2}{*}{.292} \\
\hline & Local language & 35 & .4000 & .49705 & & & \\
\hline \multirow[t]{2}{*}{ Provision for weaker section } & Odia & 91 & .7912 & .40870 & \multirow[t]{2}{*}{.086} & \multirow[t]{2}{*}{1.890} & \multirow[t]{2}{*}{.061} \\
\hline & Local language & 35 & .6286 & .49024 & & & \\
\hline \multirow[t]{2}{*}{ Admission guidelines } & Odia & 91 & .8132 & .39192 & \multirow[t]{2}{*}{.080} & \multirow[t]{2}{*}{.869} & \multirow[t]{2}{*}{.386} \\
\hline & Local language & 35 & .7429 & .44344 & & & \\
\hline \multirow[t]{2}{*}{ Duties of stakeholders } & Odia & 91 & .6593 & .47656 & \multirow[t]{2}{*}{.092} & \multirow[t]{2}{*}{1.216} & \multirow[t]{2}{*}{.226} \\
\hline & Local language & 35 & .7714 & .42604 & & & \\
\hline \multirow[t]{2}{*}{ School management } & Odia & 91 & 5.1209 & 1.20033 & \multirow[t]{2}{*}{.255} & \multirow[t]{2}{*}{$2.152 *$} & \multirow[t]{2}{*}{.033} \\
\hline & Local language & 35 & 4.5714 & 1.48097 & & & \\
\hline \multirow[t]{2}{*}{ Overall } & Odia & 91 & 21.4725 & 3.14233 & \multirow[t]{2}{*}{.632} & \multirow[t]{2}{*}{1.920} & \multirow[t]{2}{*}{.057} \\
\hline & Local language & 35 & 20.2571 & 3.28403 & & & \\
\hline
\end{tabular}

* significant at 0.05 level of significance

From the above table-10, the obtained t-ratio of overall and all component wise awareness of teachers about RTE Act with reference to their mother tongue is not significant at 0.05 levels of significance except in the component school management $(\mathrm{t}$ value $=2.152$ and $\mathrm{p}$-value $=0.033)$. The teachers with mother tongue Odia is significantly more aware about RTE Act in the component school management than the teachers with local language as mother tongue.

Awareness of Teachers about RTE Act with reference to Age

In order to study the overall and component wise awareness of teachers about RTE Act with reference to age, the data was analysed through one way ANOVA in the following table-11. 
Table-11: Summary of ANOVA depicting overall and component-wise awareness scores of teachers about RTE Act belonging to less than 30,30 to 40 and above 40 age group

\begin{tabular}{|c|c|c|c|c|c|c|}
\hline Components & Sources & df & Sum of squares & Mean square & F-ratio & p-value \\
\hline \multirow[t]{3}{*}{ Preliminary } & Between groups & 2 & 8.663 & 4.332 & \multirow{3}{*}{$3.736^{*}$} & \multirow{3}{*}{.027} \\
\hline & Within groups & 123 & 142.614 & 1.159 & & \\
\hline & Error & 125 & 151.278 & & & \\
\hline \multirow[t]{3}{*}{ RFCE } & Between groups & 2 & 1.304 & .652 & \multirow{3}{*}{2.661} & \multirow{3}{*}{.074} \\
\hline & Within groups & 123 & 30.125 & .245 & & \\
\hline & Error & 125 & 31.429 & & & \\
\hline \multirow[t]{3}{*}{ Provision for weaker section } & Between groups & 2 & .748 & .374 & \multirow{3}{*}{1.989} & \multirow{3}{*}{.141} \\
\hline & Within groups & 123 & 23.125 & .188 & & \\
\hline & Error & 125 & 23.873 & & & \\
\hline \multirow[t]{3}{*}{ Admission guidelines } & Between groups & 2 & .692 & .346 & \multirow{3}{*}{2.134} & \multirow{3}{*}{.123} \\
\hline & Within groups & 123 & 19.943 & .162 & & \\
\hline & Error & 125 & 20.635 & & & \\
\hline \multirow[t]{3}{*}{ Duties of stakeholders } & Between groups & 2 & 1.443 & .721 & \multirow{3}{*}{$3.482 *$} & \multirow{3}{*}{.034} \\
\hline & Within groups & 123 & 25.486 & .207 & & \\
\hline & Error & 125 & 26.929 & & & \\
\hline \multirow{3}{*}{ School management } & Between groups & 2 & 2.216 & 1.108 & \multirow{3}{*}{.650} & \multirow{3}{*}{.524} \\
\hline & Within groups & 123 & 209.657 & 1.705 & & \\
\hline & Error & 125 & 211.873 & & & \\
\hline \multirow[t]{3}{*}{ Overall } & Between groups & 2 & 25.349 & 12.675 & \multirow{3}{*}{1.230} & \multirow{3}{*}{.296} \\
\hline & Within groups & 123 & 1267.357 & 10.304 & & \\
\hline & Error & 125 & 1292.706 & & & \\
\hline
\end{tabular}

\section{*Significant at 0.05 level of significance}

From the above table-11, it is revealed that the calculated F-ratio of overall awareness of teachers about RTE Act belonging to less than 30, 30 to 40 and above 40 age group are not significant at 0.05 level of significance with df $2 / 123$. However, significant difference was found at 0.05 level of significance among teachers belonging to less than 30,30 to 40 and above 40 age group with respect to dimensions preliminary and duties of stakeholders of RTE Act. It indicates that there is a significant difference in the awareness about RTE Act with respect to dimensions preliminary and duties of stakeholders among elementary school teachers of less than 30,30 to 40 and above 40 age group.

\section{Major Findings}

- Elementary school teachers in tribal areas of Odisha are aware about Right to Education Act.

- There is a significant difference in the awareness about RTE Act among elementary school teachers in tribal areas of Kalahandi, Nabarangpur, Mayurbhanj and Koraput districts. Teachers of Kalahandi District are significantly more aware than the teachers of Koraput district about RTE Act.

- There is no significant difference in the awareness about RTE Act between male and female teachers.

- No significant difference was found in overall and component wise awareness of teachers about RTE Act with reference to their educational and professional qualification.

- No significant difference was found in overall and component wise awareness of teachers about RTE Act with reference to their teaching experience except in the component Right of children to free education (RCFE).

- No significant difference was found in overall and component wise awareness of teachers about RTE Act with reference to their mother tongue except in the component school management. The teachers with mother tongue Odia is significantly more aware about RTE Act in the component school management than the teachers with local language as mother tongue.

- No significant difference was found in overall and component wise awareness of teachers about RTE Act with reference to their age except in the component preliminary and duties of stakeholders.

\section{Discussion}

RTE Act has been implemented in the state of Odisha since 2010. Odisha is the second state in the country to have passed the Right of Children to Free and Compulsory Education Rule 2010. Since then, number of initiatives have been taken both by the Central and state government towards implementation of the RTE Act, 2009. Some of them are Teacher capacity building and improvement in teaching learning processes (Sadhan \& Samadhan); development of variety of materials like, booklets containing RTE Act, 2009 and Odisha RCFCE 
Rule, 2010, Trifold leaflets on provisions of the RTE Act, Handbook on FAQs on RTE, Comprehensive Handbook on RTE Act, Rules and FAQs, Posters on provisions of the RTE Act, Short film on the provisions of RTE Act, 2009, etc. Secondly, all the teachers at elementary level of Odisha are not scheduled tribe nor all of them belong to tribal areas. Teachers from mainland are also appointed in tribal areas. This may be the reason that elementary school teachers in tribal areas of Odisha are aware about Right to Education Act. Again, since the training programmes were mandatory for all the teachers and the materials were meant for all categories of teachers, no significant difference was found in awareness about RTE Act among teachers on the bases of their gender, educational and professional qualification, teaching experience, mother and age.

Hence, the Government at State and National level should focus more on providing teacher training how to implement the tenets of RTE Act in their own context and improve the quality of elementary education instead of focussing on creating awareness about RTE Act. Training and motivation should be given for: Identification of out-of-school and drop-out children in the locality and enrol them into school; collaboration with NGOs and community organizations; minimizing student absenteeism; minimising teacher absenteeism; emphasizing childcentred activity-based learning; creating awareness about RTE Act among parents and SMC members in tribal areas of Odisha; ensuring timely distribution of free text books, stationeries, uniforms, etc.; and creating a symbiotic relationship with the community.

\section{References}

Abdul, G.K. \& Rajan, A.V. (2008). Child rights: need for better awareness among student teachers. The Primary Teacher, 33 (1\&2), 86-93.

Choudhary, S. (2014). Right to education Act 2009: Letting disadvantaged children down? International Research Journal of Social Sciences, 3 (8), 1-7. Website: http://shodh.inflibnet.ac.in/bitstream/ 123456789/2827/3/03_literature\%20review.pdf

Government of India, Department of School Education and Literacy, MHRD (2009). The Right of Children to Free and Compulsory Education Act, 2009. Website: http://ssa.nic.in/rte-docs/Final_RTE_4th_Year.pdf.

Government of Orissa, School and Mass Education Department (2010). The Orissa Right of Children to Free and Compulsory Education Rule, 2010. Website:http://opepa.in/pvtrte/PDF/Circulars/ODISHA_RULESRCFCE.pdf

Islam, M.N. \& Chakraborty, N. (2013). A Study on the awareness of equitable quality in the light of RTE Act 2009 among in-service school teachers. Journal of Applied Research, 3(6), 142-143.

Kaur, R. (2015). Awareness of Right to Education Act among secondary school teachers. Online International Interdisciplinary Research Journal, 5, 283-288.

Krishnarao, G. M. \& Mangesh, G.S. (2015). A study of awareness of school teachers towards Right to Education Act-2009. Research Front, 5, 9-12.

Kumar, R.V. (2015). Awareness of RTE Act, 2009 among the prospective teachers at secondary level. PARIPEX - Indian Journal of Research, 4 (8), 296-298.

Kumar, T. P. (2014). A study of Right to Education Act among school teachers with respect to few selected background variables. Indian Journal of Applied Research, 4 (2), 15-16.

Kumari, S. \& Allam. M. (2014). Awareness among primary school teachers regarding the Right to Education Act 2009. European Academic Research, 2 (1), 983-995.

Mahanadi, M. (2014). Awareness of teachers on RTE Act-2009- A study. Right to Education: Issues and challenges. 327- 328. Cited in Gaddipati, I. (2015). The issues relating to RTE implementation and challenges: A qualitative study. Masters Dissertation, Christ University, Bengaluru. Website: http://repository.christuniversity.in /7123/1/final_dissertation_ishita_g.pdf

OPEPA, Govt. of Odisha (2015). Status of Elementary and Secondary Education in Odisha 2014-15. Website: http://opepa.odisha.gov.in/website/Download/2014-15-booklet.pdf

Patel, S. P. (2015). A comparative study of awareness towards Right to Education Act among B.Ed. trainees of Gandhinagar. International Journal of Research in Humanities \& Social Sciences, 3 (2), 29-31.

Sahu, K. K. (2014). Myths and realities of tribal education: A primary study in Similipal area of Odisha. International Journal of Humanities and Social Science Invention, 3 (4), 01-06.

Sarvapalli, R. (2012). Right to education: role of the private sector. Kolkata, India: Ernst \& Young Pvt. Ltd. Website: http://www.ey.com/Publication/ vwLUAssets/EY-Right-to-education/\$ FILE/EY-Right-toeducation.pdf.

Soni, R.B.L. (2013a). Status of implementation of RTE Act-2009 in context of disadvantaged children at elementary stage. New Delhi: Department of Elementary Education, NCERT. Website: http://www.ncert.nic.in/departm ents /nie/dee/publication/pdf/Special_Provisions_effects.pdf.

Thakur, N. (2014). Awareness of trained school teachers in relation to RTE Act at elementary level. American International Journal of Research in Humanities, Arts and Social Sciences, 6 (1), 67-71. 


\section{About the Author}

Dr. Sudarshan Mishra is presently Head, Department of Education, Ravenshaw University, Cuttack, Odisha, India. He has been teaching subjects like, Sociology of Education, Trends and Issues in Education and Research Methodology in Education for last fifteen years to undergraduate, postgraduate and Doctoral students. His major areas of research interest is Elementary Education. 